\title{
IDENTIFYING FINANCIAL MANAGEMENT BEHAVIOR IN MILLENIAL GENERATION
}

\author{
Novia Junita ${ }^{1}$, Robin $^{2}$, Yulfiswandi ${ }^{3}$ \\ 1,2,3Universitas Internasional Batam, Kota Batam/Kepulauan Riau, Indonesia \\ Email Korespondensi: ${ }^{2}$ robin@uib.ac.id
}

\begin{abstract}
This study aims to examine the effect of financial knowledge, financial attitudes, financial socialization, locus of control on financial management behavior. The research sample is the millennial generation in Batam City which was selected by purposive sampling method who were born in 1984-1999. Research data were collected by questionnaire. The data were analyzed using normality, validity, heteroscedasticity, and $t$ and $F$ tests. The results of this study concluded that financial knowledge, financial attitudes, primary agents of financial socialization, secondary agents of financial socialization, childhood consumer experiences had a significant positive effect on financial management behavior, while other variables are not significant. The managerial implications are doing financial planning, building a saving pattern, having a sense of responsibility, and setting financial goals. Parents are expected to provide financial concepts since childhood, build the habit of saving since childhood by giving pocket money and teach how to allocate money.
\end{abstract}

\section{Keywords: financial attitude; financial knowledge; financial management behavior; financial socialization}

\section{ABSTRAK}

Penelitian ini bertujuan untuk meneliti pengaruh pengetahuan keuangan, sikap keuangan, sosialisasi keuangan, locus of control terhadap perilaku pengelolaan keuangan. Sampel penelitian adalah generasi milenial di Kota Batam yang dipilih dengan metode purposive sampling yang lahir pada tahun 1984-1999. Data penelitian dikumpulkan dengan kuesioner. Data dianalisis menggunakan uji normalitas, validitas, heteroskedesitas, dan uji t dan F. Hasil penelitian ini menyimpulkan bahwa pengetahuan keuangan, sikap keuangan, agen primer sosialisasi keuangan, agen sekunder sosialisasi keuangan, pengalaman konsumen masa kecil berpengaruh signifikan positif terhadap perilaku pengelolaan keuangan, sedangkan variabel lainnya tidak signfikan. Implikasi manajerial adalah melakukan perencanaan keuangan, membangun pola menabung, memiliki rasa tanggung jawab, dan menetapkan tujuan keuangan. Orang tua diharapkan memberikan konsep keuangan sejak kecil, membangun kebiasaan menabung sejak kecil dengan memberikan uang saku dan mengajarkan cara mengalokasikan uang.

Kata Kunci: pengetahuan keuangan; perilaku pengelolan keuangan; sikap keuangan; sosialisasi keuangan

\section{ARTICLE INFORMATION}

Article History: submitted: September 2, 2021; revised: November 11, 2021; accepted: December 24,2021

JEL Classification: G40

How to cite: Junita, N., Robin, \& Yulfiswandi. (2021). Identifying Financial Management Behavior in Millenial Generation. JIMFE (Jurnal Ilmiah Manajemen Fakultas Ekonomi), 7(2), $217-230$. https://doi.org/10.34203/jimfe.v7i2.3881

\section{INTRODUCTION}

Financial management is inseparable from the development of technology, at the time of the industrial revolution 4.0, especially the millennial generation. Starting from payment instruments, fund transfers, and fundraising (Kusani et al., 2019). This millennial generation is in its productive age and dominates the 
Novita Junita: Identifying Financial Management ...

Indonesian population. This generation has characteristics such as prefer to make non-cash payments, online shopping, and like to spend money rather than save it (Kusani et al., 2019, Ida et al., 2020). The second difference with its previous generation is that a lot of use of high-cost alternative financial services, such as a loan for employees, prepaid debit cards, and mobile payments (Mottola, 2014).

A person's ability to manage daily funds is known as financial management behavior which includes budgeting, managing, controlling, finding, and saving own funds (Asandimitra \& Kautsar, 2019). In good financial handling behavior, knowledge of finances is very much needed, so that there is no less optimal on financial decision making, thus being able to manage each individual's finances by having financial management behavior (Asandimitra \& Kautsar, 2019). Kim et al., (2015) show that the millennial generation has much broader knowledge than the previous generation such as retirement plans and personal savings, where this knowledge will change financial management behavior. It is not enough that having knowledge only, but must be followed by financial attitudes, namely one's assessment of finances, more towards ways of thinking, opinions, and assessments of individual finances that are applied through attitudes so that they can manage its finances (Kusani et al., 2019, Dwiastanti, 2017). Financial attitudes can shape the style or way people shopping, spending money, deposit, and save money (Siswanti \& Halida, 2020).

The socialization process includes the collection of life events and personal interactions that provide children and adolescents with opportunities to develop financial skills and knowledge (Harrison et al., 2014). These people include financial socialization agents where families have an important role in money management, by providing knowledge and teaching proper money management that can help them to make the right financial decisions and achieve financial freedom in the early stages of their lives (Sundarasen et al., 2016). As information is given and practiced since childhood such as motivating to save and invest, over time it will improve financial management behavior, which is a childhood consumer experience (Ullah \& Yusheng, 2020). Especially the millennial generation, they are starting to get to know the world through stories or childhood experiences (Cwynar, 2020). With information and experience from an early age, these individuals will be smarter in managing financial management behavior (Ramadhan \& Asandimitra, 2019).

Considering millennial generation is on productive age who are working to having income and most contribute consuming, the population around 475.928 people or $49,86 \%$ almost $50 \%$ of the population in Batam while generation $Z$ and alpha added up only having 36,18\% on 2020 (Central Agency on Statistic, 2020). The millennial generation is a unique generation because they are creative, confident, and connected generation (3C) which means good at socializing (Ali \& Purwandi, 2017). Besides they are 3C, they are a big spender too, every generation having their characteristic lifestyle, in a millennial generation, they are always consumptive on trending items. It is making the millennial generation always be updated on trends (Carrasco \& Gallego, 2017).

Based on Bank Indonesia survey data Batam city having a highest property price increasing among 18 cities, are Bandung, Bandar Lampung, Banjarmasin, Denpasar, Palembang, Semarang, Yogyakarta, Padang, Medan, Makassar, Manado, Surabaya, Pontianak, Batam, Balikpapan, Jabodebek-Banten, Pekanbaru, Samarinda. From 0,18\% property price growth on quarter 1 in 2021 to 2,42\% growth on quarter 2 in 2021, it is the fastest increase than 18 cities. On data reveals that in Indonesia quarter 22021 having increasing property prices $1,49 \%$ year to year, besides that property sales have decreased by $10.01 \%$ year to year. From data can see that $75,08 \%$ sources of financing from debt, especially homeownership loan. Considering the information provides, afraid that the millennial generation facing a financial problem and is stuck in debt especially those who do not have good financial management behavior. From the living cost element, Batam City is the top ten highest living cost (Central Agency on Statistic, 2020). 
Cause of generation millennials is growing up in technology, they are skillful in using technology like investment activity such as buy share stock, foreign exchange, mutual funds, and other activities which can be done online. Apart from investment, they are more likely to have online transactions using a mobile phone, e-money, e-wallet even the cost using mobile phone transaction is more expensive, but they think it is still affordable, a little bit expensive does not matter, this is millennial generations habit. They do not care about the additional fee like admin fees, transaction fees, the fee charged. The millennial generation itself has different characteristics from the previous generation, both in terms of expenditure and in terms of income, this is because this generation lives in a time when technology is developing so that knowledge, interaction, and attitudes become broader, so that the financial management of the millennial generation is different from other generations (Kusani et al., 2019). Based on the phenomena expressed, this study aims to identifying financial management behavior in Batam's millenial generation.

\section{LITERATURE REVIEW AND HYPOTHESIS DEVELOPMENT}

\section{Financial Management Behavior}

Financial management behavior is a person's ability to manage his financial funds daily which includes the actions of budgeting, managing, controlling, finding, and storing his funds (Asandimitra \& Kautsar, 2019). The science of financial management behavior explains how a person makes decisions in managing funding sources (Gitman \& Zutter, 2015). Individuals who master the skill of financial management treat their financial management well, these individuals are more likely to get used to the preparation of financial planning, carry out planning with self-control, evaluate initial planning actions that are not following the conditions that occur and their implementation, overcome financial problems improvement, and always monitor improvement condition of financial problems (Prihartono \& Asandimitra, 2018). Financial management behavior can arise because of the impact of the desire to be fulfilled based on income (Ramadhan \& Asandimitra, 2019).

\section{Financial Knowledge}

Understanding of economics science related to financial understanding which is obtained through formal education such as schools, lectures, seminars that can form financial skills, with these skills to form financial management effectively and efficiently to create a prosperous life categorized as financial knowledge. In general, inadequate financial knowledge results from a lack of education. The existence of education produces sufficient knowledge and is more effective in making decisions (Prihartono \& Asandimitra, 2018). Given the characteristics of the millennial generation who are more proficient with communication and digital media, even digital technology is not excluded. They gain more knowledge through digital than conventional knowledge obtained through the offline seminar, lectures, and workshops. The generation millennial easier to obtain income but the other side, there is consumerism and difficult in balancing financial. For this reason, millennial generation knowledge is very important in financial management behavior (Kusani et al., 2019). Sutrisno \& Permatasari's research (2020) shows that although the millennial generation has a wasteful lifestyle. They still set aside money for investment for the future. This investment action is one of the financial management behaviors.

From previous paragraph explanation, we can conclude more knowledge shall build the better financial management behavior. Other research also conclude that wider knowledge will create good financial management behavior (Kim et al., 2015). This is in line with research (Mien \& Thao, 2015), Kusani et al., (2019), and Pathirannahalage \& Abeyrathna (2020) showing that financial knowledge has a positive effect on financial management behavior.

$H_{1}$ : financial knowledge has a significant positive effect on financial management behavior. 
Novita Junita: Identifying Financial Management ...

\section{Financial Attitude}

Attitude towards one's money is how one has views and behaviors about money, the main primary need of humans is money, money can make humans think irrationally (Siswanti \& Halida, 2020). Social pressure is the condition of individuals when they have money, how do individuals deal with it, when they have a lot of money, individuals are confused about what the money is and whether they can refrain from the money they have, this affects financial management behavior, the higher a person can refrain from the money they have. owned, the better the financial management behavior (Prihartono \& Asandimitra, 2018). Kusani et al., (2019) indicate that financial attitude has a strong role in improving the financial management behavior of the millennial generation, financial attitudes in individuals help to understand how the behavior needed in finance can be in the form of regular saving, writing budget plans, and financial planning indicators. Finally, Pathirannahalage \& Abeyrathna (2020) also found that financial attitude has a positive effect on financial management behavior.

\section{$\mathrm{H}_{2}$ : financial attitude has a significant positive effect on financial management behavior.}

\section{Financial Socialization Primary Agent}

Financial socialization is someone who obtains information, both knowledge, attitudes, and skills through the internal and external environment to maximize their ability to influence financial content. (Ameliawati \& Setiyani, 2018). The number of items included in the financial socialization agent is eleven items, which are grouped into primary socialization agents and secondary socialization agents (Falahati \& Sabri, 2015).

Father, mother, brother, religion, and school agents are categorized as primary agents. It is called primary because it is the first and closest agent to provide socialization (Ramadhan \& Asandimitra, 2019). According to Akben-Selcuk (2015) found a significant positive effect on financial management behavior with parents and families who are good at managing finances and will provide information and knowledge to individuals, play a role in financial socialization to children, and discuss their financial problems to their parent so when they grow up, they will manage their finances according to the realities of real life. When agents socialize, they must include financial education to their children, so the children will get sufficient knowledge to manage finances well (Akben-Selcuk, 2015). Parents teach good habits in managing finances to the next generation to develop the potential to manage finances independently when grown up (Senevirathne et al., 2017)

$\mathrm{H}_{3}$ : Financial socialization primary agent has a significant positive effect on financial management behavior.

\section{Financial Solialization Secondary Agent}

Friends, mass media, magazines, advertisements, the internet, cell phones are categorized as secondary agents. (Falahati \& Sabri, 2015). Individual behavior is based on intentions and information obtained from each other's friends, the mass media, or from magazines, advertisements, and the internet and cell phones that underlie financial management behavior. Therefore, the more connection and information obtained, the more likely they have good financial management. The millennial generation is very closely related to digital culture and is more dependent on gadgets and the internet. They grew up with the internet and gadgets. For them, the internet has become their basic need. If we make a connection with the theory mentioned by Maslow, the internet and devices have entered the pyramid of basic needs along with clothing, food, and shelter, they get information from the media (Ramadhan \& Asandimitra, 2019). This is proved by the existence of research that has a significant positive effect between these 2 variables, namely Senevirathne et al., (2017) and Zulfaris et al. (2020) said that peer friends will provide support or teach us to be extravagant and this will affect our financial management behavior. 
$\mathrm{H}_{4}$ : financial socialization secondary agent has a significant positive effect on financial management behavior.

\section{Childhood Consumer Experience}

Individual behavior about childhoods financial behavior such as financial habits learned from home, saving behavior, namely money that is set aside and saved, to become a wise consumer is known as childhood consumer experience (Falahati \& Sabri, 2015 and Sabri et al., 2012). The earlier individuals who have financial experience tend to manage finances well because they already have the intention, experience, and information which with the following safeguards and information, it will affect financial management behavior as adults (Ramadhan \& Asandimitra, 2019). This is followed by the results (Purwidianti \& Tubastuvi, 2019) which found a significant positive on financial management behavior, the more experience you have will have an impact on financial behavior improvement. Similarly (Ullah \& Yusheng, 2020) adults gain confidence that their own self can manage finances in a better way because in childhood I have had experience, so it will help these individuals in designing good financial management behavior during adulthood.

$\mathrm{H}_{5}$ : Childhood Consumer Experience has a significant positive effect on financial management behavior.

\section{Internal Locus of Control}

Individuals who have an internal locus of control are individuals who have the belief that they can control their own financial success through their abilities and skills in controlling the financial problems they face not because of fate, destiny, and luck that control life success (Darmawan et al., 2018). As individuals are more convinced that success is in their own hands, the more they try to put the necessary effort to gain the knowledge and skills needed so as to create better financial management behavior.

$\mathrm{H}_{6}$ : Internal locus of control has a significant positive effect on financial management behavior.

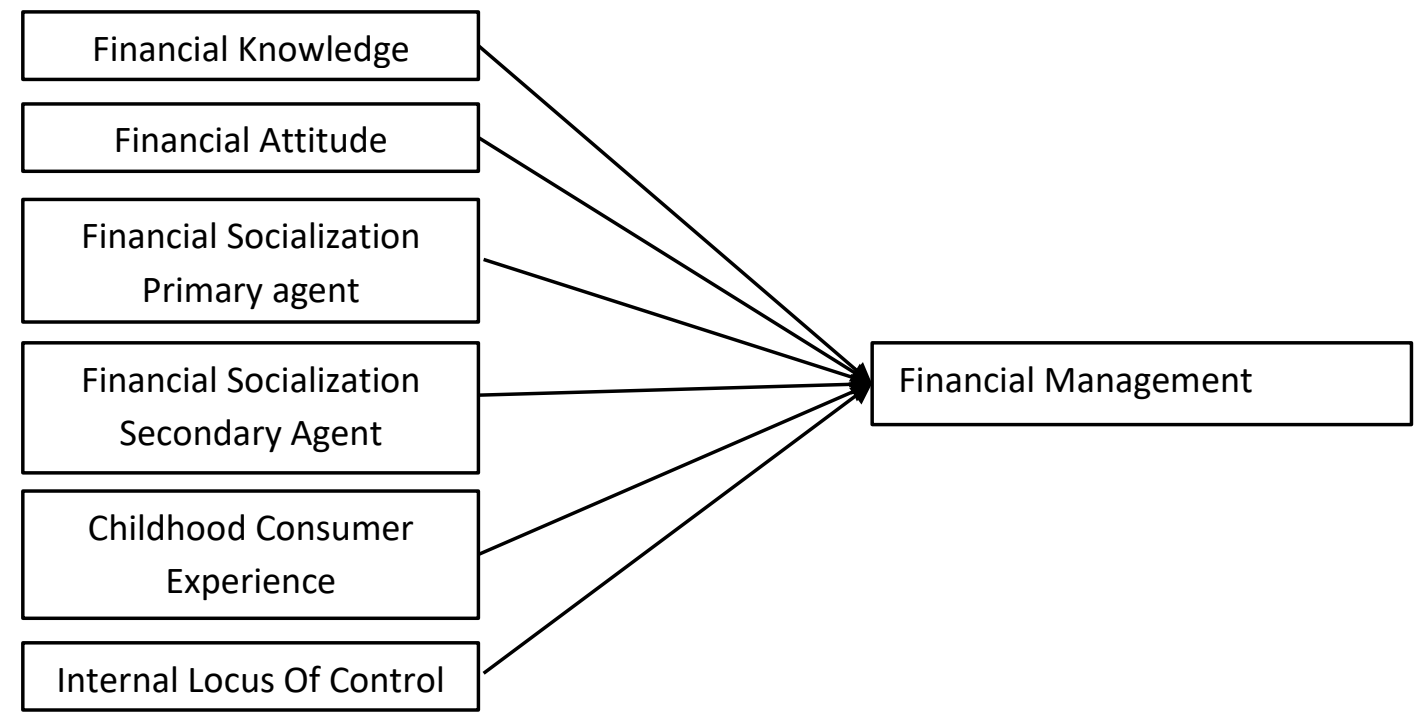

Figure 1. Research Design 
Novita Junita: Identifying Financial Management ...

\section{RESEARCH METHOD}

This research is quantitative research, where the data are analyzed statistically in the form of numbers (Indriantoro \& Supomo, 2013). In terms of classification, the research includes comparative casual research, where the research is a causal relationship between independent variables financial knowledge, financial attitude, financial socialization primary agent, financial socialization secondary agent, childhood consumer experience, and finally internal locus of control on financial management behavior. The object of research included in the study is the millennial generation of Batam City. The population of this research is millenial generation in Batam. The sampling method applied in this research is purposive sampling, where the sampling criteria arerespondents were born in 1984-1999 and respondents have income. The number of respondents applied in the study was 400 respondent data, based on the Slovin formula, which is as follows.

$$
n=\frac{N}{1+N e^{2}}
$$

Where $\mathrm{n}$ is number of samples, $\mathrm{N}$ is total population, and e is error tolerance limit. Based on the Central Agency on Statistic in 2020, the population of Batam City's millennial generation was 475.928. The error tolerance limit is $5 \%$, because the smaller the error tolerance, the more accurately the sample describes the population, which means the level of accuracy reaches $95 \%$.

Then:

$\mathrm{n}=475.928 / 1+\left(475.928 \times 0.05^{\wedge} 2\right)$

$\mathrm{n}=475.928 / 1+1.189,82$

$\mathrm{n}=475.928 / 1.190,82$

$\mathrm{n}=400$

The variables used in this study will apply Likert's scaling in answering questions assessed from one (strongly disagree), two (disagree), three (neutral), four (agree), and finally five (strongly agree) adopted from previous research. Financial management behavior and financial knowledge were adopted from Mien \& Thao (2015), the financial attitude was measured based on the research of Prihartono \& Asandimitra (2018), financial socialization primary agents and secondary agents adopt measurements from Falahati \& Sabri (2015) and Sabri et al., (2012). Finally, the adoption of childhood consumer experience is from Sabri et al., (2012), and the internal locus of control is from the research of Lestari (2020).

Questionnaires are distributed to all respondents that are matching the criteria. Total questionnaire distributed are 400 questionnaire and all returning no exception. All questionnaires are completely filled out, nineteen questionnaires are outlier and will be removed to the further test. So, total questionnaires are processable are 381 questionnaires.

\section{RESULT AND DISCUSSION}

\section{Descriptive Analysis}

The study through the collection of questionnaires which were distributed to 400 respondents according to the criteria. The data that was successfully spread were 400 respondents with nineteen outliers so that the number of data processed was 381 data. Respondent data criteria will be displayed in Table 2. The respondents divide into two gender, female are 210 of 381 respondents and other else is male respondents. Total respondents are born in 1984-1987 in this research sampling are 75 repondents of total 381. Who born in 1988-1991 having 91 respondents, for 1992-1995 are 98 respondents and other else is 1996-1999 with 132 respondents of this sampling research. The occupation of this sampling research are private employees having 242 respondents, self employeed having 115 respondents, and 
other else are 24 respondents of the total 381 respondents. All respondents are working and having their income. Who received below UMK Rp4,150,930 are 9, received UMK- 5 million rupiah are 100 respondents, and other else are above 5 million rupiah 272 respondents. It means that's there is still having employees receive salaries below minimum salary. Besides that, all respondents had to have an online shopping experience. So, it is in line with the theory and introduction that explained, millennial generation grew up within developing technology so they are more familiar with using technology.

Table 1. Respondents Data Criteria

\begin{tabular}{|c|c|c|c|}
\hline Gender & & Total & Percentage \\
\hline Female & & 210 & $55,110 \%$ \\
\hline Male & & 171 & $44,880 \%$ \\
\hline Total & & 381 & $100 \%$ \\
\hline Year of Birth & Category & Total & Percentage \\
\hline 1984-1987 & Senior millennial generation & 75 & $19,690 \%$ \\
\hline 1988-1991 & Senior millennial generation & 76 & $19,950 \%$ \\
\hline 1992-1995 & Millennial junior generation & 98 & $25,720 \%$ \\
\hline 1996-1999 & Millennial junior generation & 132 & $34,640 \%$ \\
\hline Total & & 381 & $100 \%$ \\
\hline Employment & & Total & Percentage \\
\hline Not Working & & 0 & $0,000 \%$ \\
\hline Private Employees & & 242 & $63,520 \%$ \\
\hline Civil Servants & & 0 & $0,000 \%$ \\
\hline Self-employed & & 115 & $30,180 \%$ \\
\hline Others & & 24 & $6,300 \%$ \\
\hline Total & & 381 & $100 \%$ \\
\hline Income & & Total & Percentage \\
\hline < Rp. 4,150,930 (UMK) & & 9 & $2,360 \%$ \\
\hline Rp. 4,150,930 (UMK)- Rp. 5,000,000 & & 100 & $26,250 \%$ \\
\hline > Rp. 5.000 .000 & & 272 & $71,390 \%$ \\
\hline Total & & 381 & $100 \%$ \\
\hline Ever shopped online & & Total & Percentage \\
\hline Yes & & 381 & $100 \%$ \\
\hline No & & 0 & $0 \%$ \\
\hline Total & & 381 & $100 \%$ \\
\hline
\end{tabular}

Validity and Reliability Test Results

In this test, there are several invalid questions. Invalid questions were found in the fourth-order question of financial socialization primary agent variable and the sixth question of financial socialization secondary agent variable because the load factor number is below 0,6 . These questions are religion is having a very 
Novita Junita: Identifying Financial Management ...

significant role in my financial management behavior, and magazine book is having a very significant role in my financial management behavior. For those statement many respondents answer not agree and neutral, it means that many people disagree with that, so this question are nit reliable and will be removed for further test. Where these invalid questions will be deleted and continued into the next test, which is the reliability test. The reliability test result shows that each variable is reliable, none unreliable.

Table 2. Validity Test Results Invalid

\begin{tabular}{lcc}
\hline Variable & Load Factor & Description \\
\hline Financial Socialization Primary Agent 4 & -0.001 & Invalid \\
Financial Socialization Secondary Agent 6 & 0.093 & Invalid \\
\hline
\end{tabular}

\section{Classical Assumption Test - Normality Test}

Figure 2 shows the P Plot image. From figure P Plot shows the data is normally distributed because the points follow a linear line.

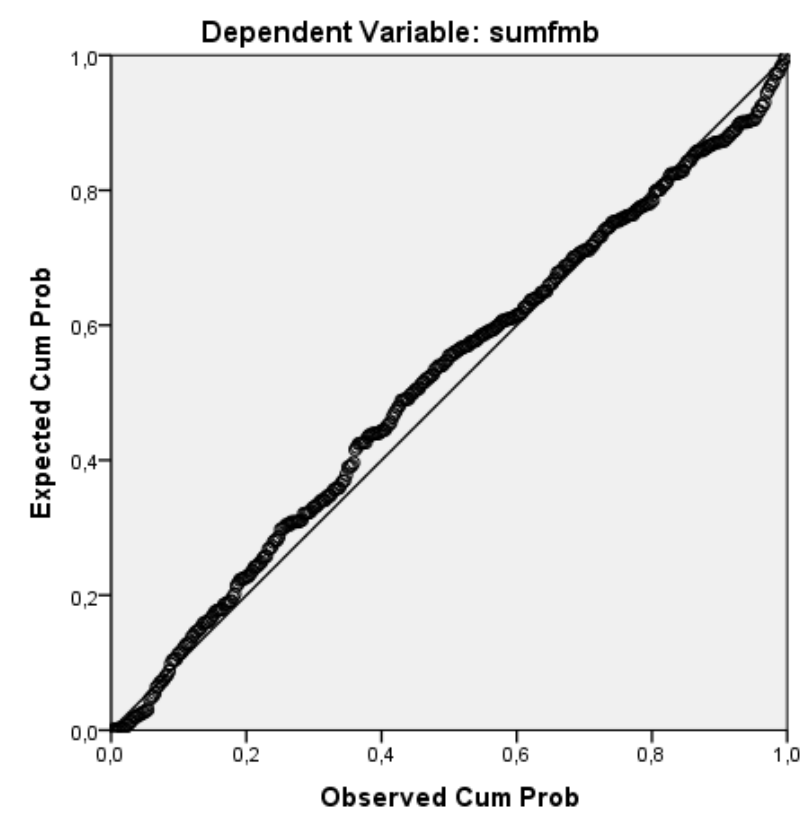

Figure 2. P Plot

\section{Classical Assumption Test - Multicollinearity Test}

Table 3 shows the multicollinearity test and the VIF value is less than 10 so this test has been fulfilled.

Table 3. Multicollinearity Test Results

\begin{tabular}{lccc}
\hline \multicolumn{1}{c}{ Variable } & Tolerance & VIF & Information \\
\hline Financial Knowledge & 0,449 & 2,228 & No Multicollinearity \\
Financial Attitude & 0,595 & 1,682 & No Multicollinearity \\
Financial Socialization-Primary Agent & 0,824 & 1,214 & No Multicollinearity \\
\hline
\end{tabular}


JIMFE (Jurnal Ilmiah Manajemen Fakultas Ekonomi)

Vol.7 No.2, Des 2021, Hal. 217-230

https://journal.unpak.ac.id/index.php/jimfe

P-ISSN: 2502-1400, E-ISSN: 2502-5678

\begin{tabular}{llll}
\hline Financial Socialization-Secondary Agent & 0,942 & 1,062 & No Multicollinearity \\
Childhood Consumer Experience & 0,444 & 2,251 & No Multicollinearity \\
Internal Locus of Control & 0992 & 1008 & No Multicollinearity
\end{tabular}

\section{Classical Assumption Test - Heteroscedasticity Test}

Figure 3 shows the heteroscedasticity test that the variables used in the study do not have heteroscedasticity because the points contained in the scatter plot are not forming a certain pattern.

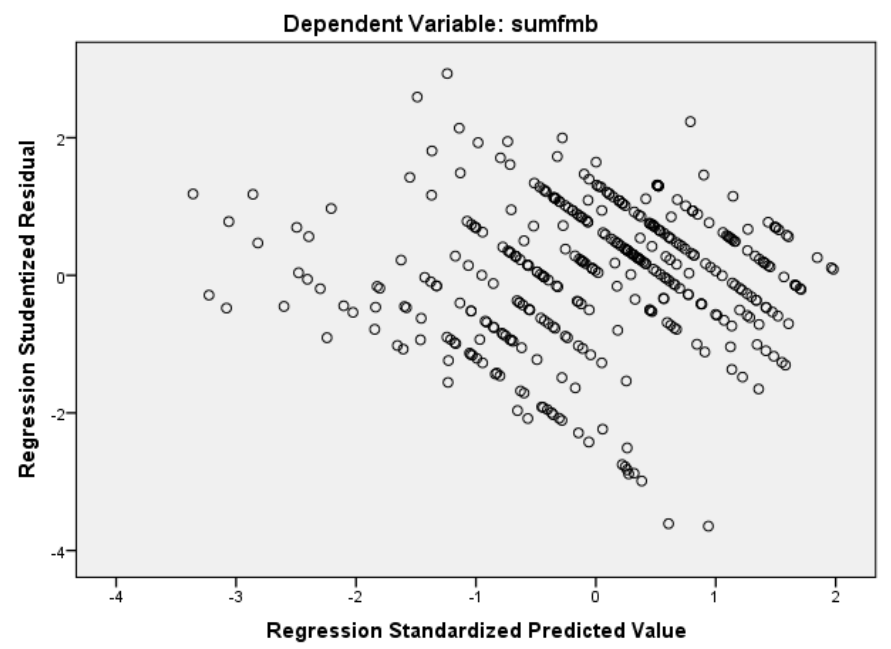

Figure 3. Scatter Plot

\section{F Test}

The data of $\mathrm{F}$ test shows that simultaneously financial knowledge, financial attitude, financial socialization primary agent, financial socialization secondary agent, childhood consumer experience, and internal locus of control have a significant effect on financial management behavior because the significance value is 0,00 , which is below 0,05 .

\section{t-test}

t-test can be seen from Table 4 significant value is below 0,05 including significant effect and vice versa.

Table 4. Results of t-test

\begin{tabular}{llll}
\hline Variable & B & Sig. & Information \\
\hline Financial Knowledge & 0,243 & 0,019 & Significantly Positive \\
Financial Attitude & 0,460 & 0,000 & Significantly Positive \\
Financial Socialization Primary Agent & 1,138 & 0,000 & Significantly Positive \\
Financial Socialization Secondary Agent & 0,179 & 0,005 & Significantly Positive \\
Childhood consumer experience & 1,190 & 0,000 & Significantly Positive \\
Internal Locus of Control & $-0,047$ & 0,599 & Not Significant \\
\hline
\end{tabular}


Novita Junita: Identifying Financial Management ...

\section{Discussion}

From the tested data that financial knowledge has a significant positive effect on financial management behavior, this hypothesis is accepted. In accordance with Siswanti \& Halida (2020) individuals who have high knowledge will be able to allocate their finances well and form self-control both to resist the urge for desire and in the provision of money and have sufficient knowledge to give confidence in solving financial problems. This is consistent with Arifin et al., (2017) having higher education will get more knowledge, this knowledge includes interest rates, credit penalties, credit knowledge, credit card bills, financial management, and investment. Which is this knowledge will form a good financial management behavior by utilizing one's knowledge of being able to control finances, pay bills on time, plan finances, fulfill needs, prepare funds for retirement savings and insurance.

Based on Table 4 shows that the second hypothesis is accepted. People who have thoughts, judgments, and opinions, about saving are not important, makes them not to do it, in contrast to the people who consider it important, their good financial attitudes will continue and even become a habit. One of the previous research got positive results between these two variables, and the millennial people of Surabaya have a good financial attitude, they prefer to buy the things they need rather than the things they want and spend money to make other people happy (Ramadhan \& Asandimitra, 2019). In contrast to individuals who always remember them, opinions, judgments, and attitudes will always continue and will become habits or behaviors that are difficult to change. The more the person can self-restrain for the money he has, the better financial management behavior will be, a good financial attitude can lead individuals to manage various financial management behaviors that will be better in managing their family finance (Siswanti \& Halida, 2020).

According to the data, this hypothesis is accepted. The first agent and closest person who provides socialization to individuals childhood which will create financial management behavior (Falahati \& Sabri, 2015). When agents socialize, they must included financial education to their children, so that they get enough knowledge to manage finances well, along with that the first agent, parents and families, have a role, that is to provide information to individual, discussing and sharing about financial problems, so that when they grow up they are more adaptable in managing finances following their own real life (AkbenSelcuk, 2015). With the first agents such as parents, they want to instill good habits in managing finances to the next generation to build the potential to manage finances independently as adults (Senevirathne et al., 2017). From school agents, along with the development of the school curriculum, schools spread knowledge about finance to students (Senevirathne et al., 2017).

The fourth hypothesis is accepted. The millennial generation is very closely related to digital culture and is more dependent on gadgets and the internet. They grew up with the internet and gadgets. For them, the internet has become their basic need. If we make a connection with the theory mentioned by Maslow, the internet and devices have entered the pyramid of basic needs along with clothing, food, and shelter, they get information from the media (Ramadhan \& Asandimitra, 2019). Likewise, with peer friends, they have a role in influencing financial management behavior, there are individuals who spend most of their time with friends, friends motivate and tell the importance of saving and remind them to spend money as needed rather than overspending, even friends provide support for planning for the future (Kadir \& Jamaluddin, 2020). When children have started to become adults, they do not depend on their parents anymore but get information from their peer friends (Senevirathne et al., 2017). A person or individual can influence each other such as supporting, providing motivation in the right way so that this individual will build the right financial management thanks to individual support or in the form of another group (Ameliawati \& Setiyani, 2018).

The data shows that this hypothesis is accepted. The earlier individuals have financial experience, they tend to manage finances well because they already have the intention, experience, and information 
(Ramadhan \& Asandimitra, 2019). This is the same as research by Ullah \& Yusheng (2020) adults gain confidence that their own self can manage finances in a better way because in childhood I had experienced, so it will help these individuals in planning good financial management behavior they grow up.

The data shows that this hypothesis is rejected. According to Masdupi et al., (2020) faith and trust alone cannot manage finances well but action must be taken. That research also explaining that internal locus of control has no significant effect because good financial management behavior is created by acquiring reliable financial skills and getting increased income that can build self-confidence not through strengthening and self-confidence without acquiring financial skills. This is also supported by Masdupi et al., (2019) finding a high internal locus of control does not create better financial management behavior nor makes individuals more responsible for their finances but has no significant effect, with adequate knowledge and awareness of the importance of financial management than when faced with financial problems, these individuals have been able to solve the problems at hand.

\section{CONCLUSIONS}

Based on the results of testing the first hypothesis $\left(\mathrm{H}_{1}\right)$ stated hypothesis is accepted. It can be concluded that financial knowledge has a significant positive effect on financial management behavior. Testing the second hypothesis $\left(\mathrm{H}_{2}\right)$ is accepted. Financial attitude has a significant positive effect on financial management behavior. The third hypothesis test $\left(\mathrm{H}_{3}\right)$ is accepted. Financial socialization from the primary agent has a significant positive effect on financial management behavior. The fourth hypothesis $\left(\mathrm{H}_{4)}\right.$ is received. Financial socialization from secondary agents has a significant positive effect on financial management behavior. The fifth hypothesis $\left(\mathrm{H}_{5}\right)$ is accepted. Childhood consumer experience has a significant positive effect on financial management behavior. Last, the sixth hypothesis $\left(\mathrm{H}_{6}\right)$ was rejected. Internal locus of control has no significant effect on financial management behavior.

The managerial implication is that the millennial generation can make financial plans, build savings patterns, a sense of responsibility, and financial goals in meeting their needs. Considering that the millennial generation has fairly good knowledge along with the education taken, but education that comes from campus or school is not up to date over time, so they can attend online financial seminars to gain more knowledge in finance. That way, they can control their finances well. In pursuing education, the millennial generation gets financial knowledge wherewith this knowledge, the millennial generation knows the importance of money management, so they have a financial attitude that can create good habits of financial management behavior. As the millennial generation, they know the importance to build a saving pattern, financial goals, a sense of responsibility, and doing financial planning. Parents are one of the important parties in influencing the financial management behavior of their children. It is better to be taught financial concepts, financial knowledge, and saving habits from a young age. By giving pocket money to children and teaching their children how to allocate money such as saving and spending, adding experience since childhood so that when they grow up, they have a sense of responsibility and habits, they will boost good financial management behavior. Not only parents but often hanging out with positive friends can teach financial matters such as invitations to seminars conducted through online forums. So, in this era of technology, mobile phones, and the internet have become a primary need for the millennial generation, even mass media such as news are online based.

\section{REFERENCES}

Akben-Selcuk, E. (2015). Factors Influencing College Students' Financial Behaviors in Turkey: Evidence from a National Survey. International Journal of Economics and Finance, 7(6), 87-94. 
Novita Junita: Identifying Financial Management ...

https://doi.org/10.5539/ijef.v7n6p87

Ameliawati, M., \& Setiyani, R. (2018). The Influence of Financial Attitude, Financial Socialization, and Financial Experience to Financial Management Behavior with Financial Literacy as the Mediation Variable. KnE Social Sciences, 3(10), 811. https://doi.org/10.18502/kss.v3i10.3174

Arifin, A. Z., Kevin, \& Siswanto, H. P. (2017). The Influence of Financial Knowledge, Financial Confidence, and Income on Financial Behavior Among the Workforce Jakarta. MIX: Jurnal IImiah Manajemen, 7(1), 37-47.

Asandimitra, N., \& Kautsar, A. (2019). The influence of financial information, financial self efficacy, and emotional intelligence to financial management behavior of female lecturer. Humanities and Social Sciences Reviews, 7(6), 1112-1124. https://doi.org/10.18510/hssr.2019.76160

Carrasco-Gallego, J. A. (2017). Introducing Economics to Millennials. International Review of Economics Education, 26, 19-29.

Central Agency on Statistic. (2020). Jumlah Penduduk Menurut Kelompok Umur Generasi (Jiwa). https://burukab.bps.go.id/indicator/12/435/1/jumlah-penduduk-menurut-kelompok-umurgenerasi.html

Cwynar, A. (2020). Financial Literacy, Behaviour and Well-Being of Millennials in Poland Compared to Previous Generations: The Insights from Three Large-Scale Surveys. Review of Economic Perspectives, 20(3), 289-335. https://doi.org/10.2478/revecp-2020-0015

Darmawan, A., Suyoto, Widhiandono, H., Utami, N. H., Razak, A. A. Z. A., \& Wahid, H. (2018). The Effect of Financial Literacy, Financial Experience, and Locus of Control Towards Financial Management Attitude and Family Investment Planning Behavior. Proceedings International Conference of Business, Accounting and Economic (ICBAE UMP 2018), 206-215.

Dwiastanti, A. (2017). Analysis of financial knowledge and financial attitude on locus of control and financial management behavior. Management and Business Review, 1(1), 1. https://doi.org/10.21067/mbr.v1i1.2043

Falahati, L., \& Sabri, M. F. (2015). An exploratory study of personal financial wellbeing determinants: Examining the moderating effect of gender. Asian Social Science, 11(4), 33-42. https://doi.org/10.5539/ass.v11n4p33

Gitman, L. J., \& Zutter, C. J. (2015). Principles of Managerial Finance. ISBN13: 9780133507690. United States: Prentice Hall.

Ida, I., Zaniarti, S., \& Wijaya, G. E. (2020). Financial Literacy, Money Attitude, Dan Financial Management Behavior Generasi Milenial. Jurnal Muara IImu Ekonomi Dan Bisnis, 4(2), 406. https://doi.org/10.24912/jmieb.v4i2.9144

Indriantoro, N., \& Supomo, B. (2013). Metodologi Penelitian Bisnis Untuk Akuntansi \& Manajemen. Yogyakarta: BPFE.

Kadir, J. M. A., \& Jamaluddin, A. A. Bin. (2020). Saving Behavior in Emerging Country: The Role of Financial Knowledge, Parent Socialization and Peer Influence. GADING (Online) Journal for Social Sciences, 23(1), 65-73.

Kim, K. T., Anderson, S. G., \& Seay, M. C. (2015). Financial Knowledge and Short-Term and Long-Term Financial Behaviors of Millennials in the United States. The Journal of Family and Economics Issues. https://doi.org/10.2504/kds.29.162_2

Kusani, A., Handayani, A., Rajiani, I., \& Saepuloh, A. (2019). Antecedents Behavioral of the Millennial Generation Financial Management. International Journal of Recent Technology and Engineering, 8(4), 1583-1588. https://doi.org/10.35940/ijrte.b3907.118419

Lestari, S. Y. (2020). Pengaruh Pendidikan Pengelolaan Keuangan Di Keluarga, Status Sosial Ekonomi, locus of control Terhadap Literasi Keuangan (Pelajar SMA Subang). Prisma (Platform Riset Mahasiswa 
Akuntansi), 1(2), 69-78.

Harrison, T, Marchant, C \& Ho, M. (2014). Conceptualising Financial Socialization. Child and Teen Consumption 2014, 1-5

Masdupi, E., Rasyid, R., \& Rahmiati. (2020). Does Locus of Control Mediate the Relationship Between Financial Knowledge and Income within Financial Management Behaviour? Evidence from Productive-Aged People in West Sumatera Indonesia. International Journal of Advanced Science and Technology, 29(05), 8393-8408. http://sersc.org/journals/index.php/IJAST/article/view/18663

Masdupi, E., Rasyid, R., \& Rahmiati. (2019). Financial Management Behavior at Productive Age Community in Bukittinggi. 124, 673-681. https://doi.org/10.2991/aebmr.k.200305.133

Mien, N. T. N., \& Thao, T. P. (2015). Factors Affecting Personal Financial Management Behaviors: Evidence from Vietnam. Proceedings of the Second Asia-Pacific Conference on Global Business, Economics, Finance and Social Sciences, 1-16.

Mottola, G. R. (2014). The Financial Capability of Young Adults - A Generational View. FINRA Foundation Financial Capability Insights. https://doi.org/10.13140/RG.2.1.3800.5281

Pathirannahalage, S., \& Abeyrathna, G. M. (2020). Factors Affecting To Personal Financial Management Behaviours Of Government Employees In Sri Lanka. International Journal of Scientific and Research Publications (IJSRP), 10(05), 761-767. https://doi.org/10.29322/ijsrp.10.05.2020.p10188

Prihartono, M. R. D., \& Asandimitra, N. (2018). Analysis Factors Influencing Financial Management Behaviour. International Journal of Academic Research in Business and Social Sciences, 8(8), 308326. https://doi.org/10.6007/ijarbss/v8-i8/4471

Purwidianti, W., \& Tubastuvi, N. (2019). The Effect of Financial Literacy and Financial Experience on SME Financial Behavior in Indonesia. Jurnal Dinamika Manajemen, 10(1), 40-45. https://doi.org/10.15294/jdm.v10i1.16937

Ramadhan, A. Y., \& Asandimitra, N. (2019). Determinants of Financial Management Behavior of Millennial Generation in Surabaya. Jurnal Minds: Manajemen Ide Dan Inspirasi, 6(2), 129. https://doi.org/10.24252/minds.v6i2.9506

Sabri, M. F., Cook, C. C., \& Gudmunson, C. G. (2012). Financial Well-Being Of Malaysian College Students. Asian Education and Development Studies, 1(2), 153-170. https://doi.org/10.1108/20463161211240124

Senevirathne, Jayendrika, \& Silva. (2017). Impact of Financial Socialization Agents Towards Financial Literacy Among Young Micro Business Entrepreneurs in Colombo District in Sri Langka [Conference Session].

ICMR. https://www.researchgate.net/publication/320547330_Financial_Literacy_and_Success_of_Micr o_Business_Evidence_from_Small_Enterprises_in_Sri_Lanka

Siswanti, I., \& Halida, A. M. (2020). Financial Knowledge, Financial Attitude, and Financial Management Behavior : Self-Control As Mediating. The International Journal of Accounting and Business Society, 28(01), 71-98. https://ijabs.ub.ac.id/index.php/ijabs/article/view/492

Sundarasen, Devi, S., Rahman, Muhammad Sabur Othman, N. S., \& Jennifer, D. (2016). Impact Of Financial Literacy, Sosialisasi keuanganAgents, And Parental Norms On Money Management. Journal Of Business Studies Quarterly, 8(1), 140-156.

Sutrisno \& Permatasari, D. (2020). Financial Behavior of Millenial Genration on Investment Decision. Journal of Critical Review, 7(19), 2237-2244.

Ullah, S., \& Yusheng, K. (2020). Financial Socialization, Childhood Experiences and Financial Well-Being: The Mediating Role of Locus of Control. Frontiers in Psychology, 11, 1-11 https://doi.org/10.3389/fpsyg.2020.02162 
Novita Junita: Identifying Financial Management ...

Zulfaris, M. D., Mustafa, H., Mahussin, N., Alam, M. K., \& Daud, Z. M. (2020). Students and money management behavior of a Malaysian public university. Journal of Asian Finance, Economics and Business, 7(3), 245-251. https://doi.org/10.13106/jafeb.2020.vol7.no3.245 